\title{
Effect of Planting Time on Sheath Blight Disease of Rice in Bangladesh
}

\author{
S Parveen ${ }^{*}$, M R Bhuiwan², M A I Khan ${ }^{3}$ and M A Ali ${ }^{4}$
}

\begin{abstract}
Sheath blight (ShB) caused by Rhizoctonia solani is one of the major disease of rice (Oryza sativa L.) in Bangladesh. Effect of planting time on ShB disease of BRRI dhan 49 was observed at the experimental plots of Bangladesh Rice Research Institute, Gazipur. Two field experiments were conducted to develop management strategy for controlling ShB during T. Aman 2010-11 seasons. Four planting dates viz. 15 July, 30 July, 15 August and 30 August were imposed to record the effect of planting time on incidence and severity of ShB disease on BRRI dhan49. Significant differences on the Relative Lesion Height (RLH) among the treatments were observed during both 2010 and 2011 seasons. For both the seasons, the highest RLH was recorded in plots transplanted on 15 August $(62.1 \%$ in 2010 and $61.2 \%$ in 2011) because of the remaining high temperature, rainfall and humidity and the lowest in plots transplanted on 30 July ( $19.4 \%$ for both). Similarly, the maximum severity score was recorded in 15 August transplanting (7) and the minimum in 30 July (1) respectively. Percent disease index (PDI) was also varied significantly among the treatments for both the seasons. During both the years, the maximum PDI was recorded in 15 August (76.5 and $75.2 \%$ respectively) and the minimum in 30 July transplanting (20.4 and 20.1 respectively). However, the highest number of filled grains panicle ${ }^{-1}$ was counted in 30 July (151), followed by15 July transplanting (145) during 2010. But, it was the highest in 30 July (141), followed by 15 August transplanting (136) during 2011. Again for both the seasons, the lowest filled grains panicle ${ }^{-1}$ was recorded in 30 August transplanting (116 and 127). Similarly for both the years, the maximum grain yield was observed in 30 July (6.29 and $5.82 \mathrm{t} \mathrm{ha}^{-1}$ respectively), followed by 15 July ( 5.67 and $\left.5.17 \mathrm{t} \mathrm{ha}^{-1}\right)$ and the lowest in 30 August transplanting ( 3.80 and $4.27 \mathrm{t} \mathrm{ha}^{-1}$ respectively). However, 1000 grain weight was $20 \mathrm{~g}$ in each date of transplanting during both the seasons. Finally, Integrated Disease Management (IDM) packages need to be developed by using appropriate planting time, cultural practices and fungicides to control ShB disease of rice.
\end{abstract}

Key words: Planting time, sheath blight incidence, rice

\section{INTRODUCTION}

Sheath blight (ShB) disease of rice, caused by Rhizoctonia solani Kuhn is a destructive disease worldwide (Nagarajkumar et al., 2004). The pathogen has a wide host range and can infect plants belonging to more than 32 families and 188 genera (Gangopadyay and Chakrabarti, 1982). In Bangladesh, ten rice diseases are considering as major (Miah and Shahjahan, 1987) and ShB is one of them. ShB infected $20.8 \%$ of the plant populations with an estimated yield loss even up to $50 \%$ (Anonymous, 2006). It is prevalent in almost all rice growing areas and seasons of
Bangladesh, but the highest intensity was found in transplanted Aus, followed by $\mathrm{T}$. Aman and Boro seasons (Anonymous, 2018). Therefore, for sustainable rice production, minimizing both the ShB epidemics and its yearly crop losses are essential in Bangladesh. Development of ShB disease depends on climatic factors, host and soil components (Damicone et al., 1993). Temperature and relative humidity (Leano, 1993), soil, inoculum of Rhizoctonia solani (Lakpale et al., 1994), plant density (Dilla, 1993) and physiologic condition of rice plants (Hashiba et al., 1977) are important for the development of ShB disease of rice.

\footnotetext{
${ }^{1}$ Senior Scientific Officer and ${ }^{3}$ Principal Scientific Officer, Training Division, BRRI, ${ }^{2}$ Senior Scientific Officer, Plant Pathology Division, BRRI, Gazipur 1701 and 4Professor, Department of Plant Pathology, Faculty of Agriculture, BAU, Mymensingh. ${ }^{*}$ Corresponding author's E-mail: parveenbrri@yahoo.com
} 
The peak stage of ShB disease is during flowering when the rice canopy is most dense, forming a microclimate favourable to pathogen growth and spread (Brooks, 2007). ShB infection during flowering or heading stage causes a reduction of total seed weight due to lower number of filled grains and consequently lower yield (Nagarajkumar et al., 2004). Other factors for ShB disease severity are the growth stage at infection, cultivar resistance and cultural practices (Groth et al., 1992). Both seedling and adult plants are equally affected by $\mathrm{ShB}$, but losses are significantly higher in seedling stage. However, the disease severity and yield loss is higher during booting stage as compared to tillering, maximum tillering or panicle initiation stage. Besides, Wu et al., (2012) reported that lodging alters the normal rice canopy design, affecting photosynthetic ability and total biomass production and causes epidemics.

Temperature and humidity are the two main factors for ShB disease development. Due to global warming, air temperature is increasing day by day, which is also favourable for rapid ShB disease development. Depending on plant age, time of infection and severity, it causes yield loss of 5.9 to $69 \%$ (Naidu, 1992). Under favourable conditions, yield losses due to ShB disease range from 4 to 50\% (Groth et al., 1991; Marchetti and Bollich, 1991). But, the average incidence of ShB in Bangladesh is about 20.3\% (Ali et al., 2003) and may ranges from 14 to $31 \%$ under farmer's field condition (Shahjahan et al., 1986).

The control of ShB disease is depended mainly on fungicides by the farmers. But, it is not considered sustainable due to its toxic residual effects, potential risk of emergence of races of the pathogen overtime and different environmental hazards. Ashrafuzzaman et al. (2005) also emphasized on different management options to control ShB disease.
Therefore, there is an ample scope to use different cultural practices for managing ShB. The optimum planting time is one of the important options, because, ShB disease development can be avoided in optimum planting time, as comparing to the late transplanting, particularly in Boro season (Hossain and Mia, 2001). Therefore, considering the above facts, the present study was designed to determine the optimum planting time of rice for managing the ShB disease of rice with the aim of recommending IDM strategy for rice field in Bangladesh.

\section{MATERIALS AND METHODS}

Field experiment, design and treatment. Two experiments were conducted at BRRI experiment field in Gazipur under artificial inoculation condition during T. Aman 2010-11 seasons. A levee was made surrounding the plots to maintain standing water up to $5.0 \mathrm{~cm}$ inside. Land was prepared 15 days before transplanting. Ploughing and cross ploughing followed by laddering was done by power tiller. Weeds were cleaned manually. Thirtyday-old and 2-3 seedlings per hill of BRRI dhan 49 were transplanted with $20 \mathrm{~cm} \times 15 \mathrm{~cm}$ spacing. The experiment was laid in RCBD with four replications. The individual plot size was $2.0 \times 2.0 \mathrm{~m}^{2}$. Each plot was separated from the other by a two-hill-wide border. The blocks were separated by a $0.5 \mathrm{~m}$ path including a levee. Fertilizers were applied @ 405: 150: 202: 135: 10 g decimal $^{-1}$ of urea, TSP, MOP, gypsum and zinc sulphate respectively. All fertilizers were applied in basal, except urea. For agronomic practices such as weed, irrigation, drainage and insect management current standard recommendations were followed (Anonymous, 2010). Four transplanting dates were evaluated as treatments: $T_{1}=15$ July, $T_{2}=$ 30 July, $T_{3}=15$ August and $T_{4}=30$ August. 
Preparation of inoculum. One hundred PDA plates in glass petridishes were prepared following the standard procedure. The fungus (Rhizoctonia solani) was grown in the petridishes containing PDA medium and incubated for seven days at room temperature $\left(25\right.$ to $30^{\circ} \mathrm{C}$ ) for growth and development of the pathogen.

Inoculation of pathogen. Inoculations were done at maximum tillering stage (Bhaktavatsalam et al., 1978). The plants were inoculated with Rhizoctonia solani culture (7 days) grown on PDA medium. Prior to inoculation, eight hills were tagged randomly in the central area of each plot. Inoculation was done by inserting a piece of culture medium (cutting the culture medium into eight pieces) at the middle of each hill in the afternoon, colonized by the ShB pathogen in a tagged rice hill and maintained standing water onward of the crop growth to maintain high moisture below canopy level for disease development (Sharma and Teng, 1990).

Data collection. Disease data were collected at the hard dough stage. Twenty-five hills were selected at random from each experimental unit. Number of infected tillers and hills were counted. Incidence was recorded by tiller infection and expressed in percentage, while severity by relative lesion height (RLH) and percent disease index (PDI) (McKinney, 1923). Standard Evaluation System (SES) for rice (IRRI, 2002) was used for calculation of PDI. Data were recorded for each treatment following SES for rice in 0-9 scale (Table 1).

Data on total tiller, infected tiller, plant height, panicles $\mathrm{m}^{-2}$, filled grain, unfilled grain, 1000 grain weight and grain yield were recorded. Grain yield was expressed in $\mathrm{t} \mathrm{ha}^{-1}$.
Table 1. Standard Evaluation System for ShB disease of rice.

\begin{tabular}{l|l}
\hline \multicolumn{2}{|c}{ SCALE (based on relative lesion height) } \\
\hline 0 & No infection observed \\
1 & Lesions limited to lower 20\% of the plant height \\
3 & $20-30 \%$ \\
5 & $31-45 \%$ \\
7 & $46-65 \%$ \\
9 & More than $65 \%$ \\
\hline
\end{tabular}

Note: The relative lesion height is the average vertical height of the uppermost lesion on leaf or sheath expressed as a percentage of the average plant height.

$$
\begin{aligned}
& \mathrm{RLH}=\frac{\text { Lesion height }(\mathrm{cm})}{\text { Plant height }(\mathrm{cm})} \times 100 \\
& \text { PDI = - Total rating } \\
& \text { No. of observation } \times \text { Maximum grade }
\end{aligned}
$$

Statistical analysis. The data were subjected to statistical analysis and ANOVA (analysis of variance) was constructed by SPSS 2.05 programme. Microsoft Excel 2010 was used for data management. The treatment means were compared by LSD test at probability level $\mathrm{P}=0.05$.

Weather data. The maximum and minimum air temperature, relative humidity and rainfall data from 2010 to 2011 were collected from meteorological station at BRRI, Gazipur.

\section{RESULT AND DISCUSSION}

Effect of planting time on ShB disease incidence and severity. Table 2 shows the effect of planting time on the development of ShB disease of rice during T. Aman 2010. Significant differences on the RLH among the transplanting dates were observed. The highest RLH was recorded in plots transplanted on 15 August (62.1\%) and the lowest was in plots transplanted on 30 July (19.4). However, the RLH was $22.80 \%$ in 15 July and $44.9 \%$ in 30 August transplanting. The difference in RLH between 15 July and 30 July 
transplanting was not significant. But RLH of 30 August was significantly lower from 15 August transplanting and significantly higher over 15 July and 30 July transplanting. However, higher RLH was found in 15 August than 15 July. Severity score of ShB disease was also the maximum in 15 August transplanting (7). It was 5 in plots transplanted on 30 August and 3 in plots transplanted on 15 July. However, the minimum score of severity (1) was in 30 July transplanting. PDI varied significantly among the transplanting dates. The maximum PDI was recorded in 15 August $(76.5 \%)$ and the minimum in 30 July transplanting (20.4). Significant differences in PDI were observed between 15 July and 30 July, 30 July and 15 August, 15 July and 15 August and 15 and 30 August transplanting respectively.

Table 3 shows the effect of transplanting time on development of ShB disease of rice during T. Aman 2011. RLH was as high as 61.20\% in 15 August and 44.20\% in 30 August transplanting. However, the RLH was $23.0 \%$ in 15 July and $19.40 \%$ in 30 July transplanting. The difference in RLH between these two transplanting dates was not significant. Similarly difference between 15 July and 30 July transplanting was not significant. But difference between 15 July and 15 August, 15 July and 30 August, 30 July and 15 August as well as 30 July and 30 August transplanting were significant. The minimum (1) severity score of ShB was recorded in 30 July transplanting and the maximum (7) in 15 August transplanting followed by 5 in 30 August and 3 in 15 July transplanting. PDI also differed significantly among the transplanting dates of BRRI dhan49. It was the maximum in 15 August (75.23\%) and the minimum in 30 July (20.14) transplanting. Significant variation in PDI between 30 July and 30 August (59.7\%) transplanting was recorded. Likewise the variation in PDI between 15 July (37.6\%) and 15 August was significant.
Table 2. Effect of planting time of BRRI dhan 49 on the development of ShB disease during T. Aman, 2010.

\begin{tabular}{cccc} 
Treatment & RLH (\%) & Severity score & PDI \\
\hline $\mathrm{T}_{1}$ & $22.80 \mathrm{c}$ & 3 & $40.20 \mathrm{c}$ \\
$\mathrm{T}_{2}$ & $19.44 \mathrm{c}$ & 1 & $20.40 \mathrm{~d}$ \\
$\mathrm{~T}_{3}$ & $62.10 \mathrm{a}$ & 7 & $76.50 \mathrm{a}$ \\
$\mathrm{T}_{4}$ & $44.88 \mathrm{~b}$ & 5 & $68.40 \mathrm{~b}$ \\
$\mathrm{LSD}$ & 11.88 & & 4.60 \\
$(\mathrm{P}=0.05)$ & & & \\
\hline
\end{tabular}

$\mathrm{T}_{1}=15$ July, $\mathrm{T}_{2}=30$ July, $\mathrm{T}_{3}=15$ August and $\mathrm{T}_{4}=30$ August transplanting. Means followed by the same letter in a column did not differ significantly at the $5 \%$ level by LSD, PDI=Percent disease index, RLH=Relative lesion height. Severity score 1=Lesions limited to lower than $20 \%$ of plant height, $3=20-30 \%, 5=31-45 \%, 7=46-65 \%$ and $9=$ More than $65 \%$.

Table 3. Effect of planting time of BRRI dhan 49 on ShB disease development during T. Aman 2011.

\begin{tabular}{cccc}
\hline Treatment & RLH (\%) & Severity score & PDI \\
\hline $\mathrm{T}_{1}$ & $23 \mathrm{c}$ & 3 & $37.62 \mathrm{c}$ \\
$\mathrm{T}_{2}$ & $19.40 \mathrm{c}$ & 1 & $20.14 \mathrm{~d}$ \\
$\mathrm{~T}_{3}$ & $61.20 \mathrm{a}$ & 7 & $75.23 \mathrm{a}$ \\
$\mathrm{T}_{4}$ & $44.20 \mathrm{~b}$ & 5 & $59.67 \mathrm{~b}$ \\
$\mathrm{LSD}$ & 15.62 & & 10.79 \\
$(\mathrm{P}=0.05)$ & & & \\
\hline
\end{tabular}

$\mathrm{T}_{1}=15$ July, $\mathrm{T}_{2}=30$ July, $\mathrm{T}_{3}=15$ August and $\mathrm{T}_{4}=30$ August transplanting. Means followed by the same letter in a column did not differ significantly at the $5 \%$ level by LSD.

Effect of weather factors on planting times for ShB disease incidence and severity. It is evident from the results of the study that planting times had significant effect on ShB disease incidence and severity of rice in the fields. Significant differences on the RLH, severity score and PDI among the treatments for both the seasons were observed. The RLH, severity score and PDI were found significantly higher in 15 August transplanting than 30 July (Fig. 1) as well as 15 July transplanting (Fig. 2) during T. Aman 2010, because of the remaining high temperature, rainfall and relative humidity ( 9 am and $2 \mathrm{pm}$ ) during 15 August than 15 and 30 July 2010 respectively. Moreover, the microclimate at the 


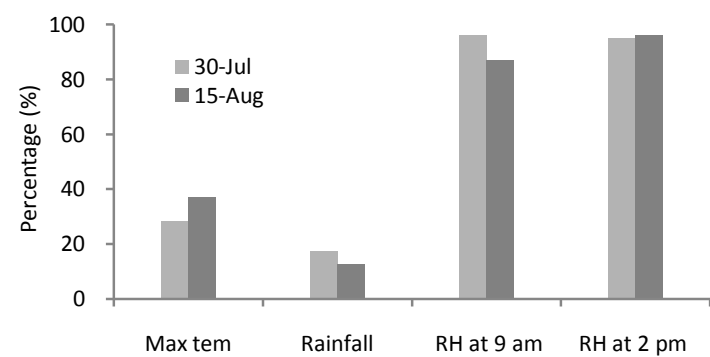

Fig. 1. Temperature, rainfall and relative humidity during 30 July and 15 August 2010.

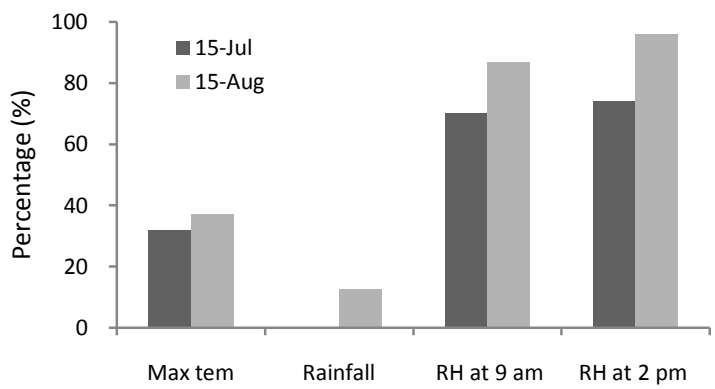

Fig. 2. Temperature, rainfall and relative humidity during 15 July and 15 August 2010.

maximum tillering stage of BRRI dhan 49 became more favourable in the season due to 15 August transplanting in Bangladesh. Kozaka (1975) narrated similar observations in Japan for epidemic development of ShB. Similarly, Ui et al. (1976) observed that the RLH became higher under the favourable microclimate within the canopy of the rice hills.

Similarly, the RLH, severity score and PDI were also found significantly higher in 15 August transplanting than 30 July (Fig. 3) as well as 15 July transplanting (Fig. 4) during T. Aman 2011, due to higher temperature, rainfall and relative humidity ( 9 am and 2 pm) during 15 August than 15 and 30 July 2011 respectively.

Effect of planting time on yield components. Table 4 shows that planting time had significant effect on the yield and yield components of BRRI dhan49. Number of panicles $\mathrm{m}^{-2}$ was the highest (268) in 30 August transplanting and was statistically similar to 30 July (263) and 15 July (257) transplanting. However, panicles $\mathrm{m}^{-2}$ was significantly lower (244) in 15 August transplanting. Number of panicles $\mathrm{m}^{-2}$ in 15 July transplanting was statistically similar to 30 July transplanting. The highest number of filled grains panicle-1 (151) was counted in 30 July, followed by 15 July transplanting (145) grains panicle-1. The lowest number of filled grains panicle-1 (116) was recorded in 30 August transplanting. However, it was 127 in 15 August and was significantly differed from that of 30 August transplanting (116). The maximum number of unfilled grains (74) was counted from a panicle in 30 August transplanting and the minimum in 30 July transplanting (39). However, it was 63 in 15 August and 45 in 15 July transplanting. The number of unfilled grains in plots transplanted on 15 July did not differ from that of 30 July, but the number of unfilled grains in 30 July and 15 August transplanting varied significantly between 15 August and 30 August transplanting. Grain yield was the maximum (6.29 $\left.\mathrm{t} \mathrm{ha}^{-1}\right)$ in 30 July and it was $5.67 \mathrm{t} \mathrm{ha}^{-1}$ in 15 July transplanting. The difference in grain yield between 15 July and 30 July transplanting was significant. However, the difference in grain yield between 15 August (4.17 $\mathrm{t} \mathrm{ha}^{-1}$ ) and 30 August (3.80) was insignificant. But, grain yield of 15 August transplanting was significantly lower than that of 15 July transplanting. Shahjahan et al. (1986) also reported that the losses caused by ShB disease in Bangladesh may ranges from 14 to $31 \%$ under farmer's field condition. Finally, the transplanting dates did not affect grain weight of BRRI dhan49. The weight of 1000 grains was $20 \mathrm{~g}$ in each transplanting date during $\mathrm{T}$. Aman 2010. 


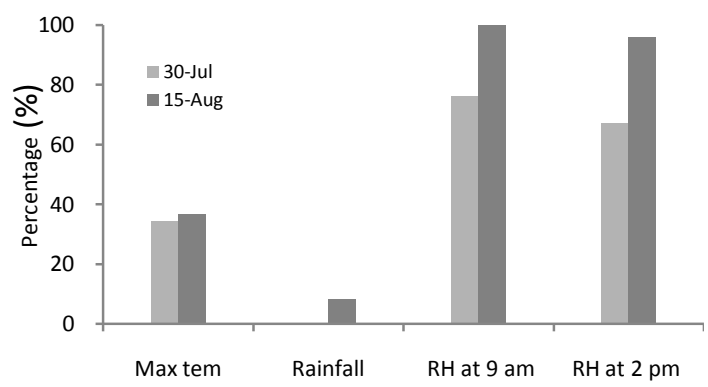

Fig. 3. Temperature, rainfall and relative humidity during 30 July and 15 August 2011.

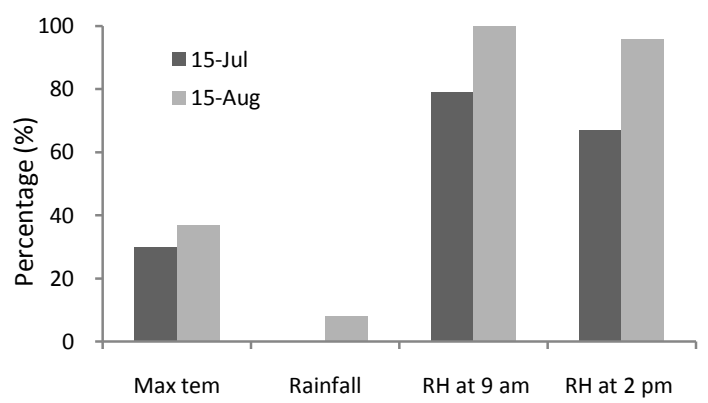

Fig. 4. Temperature, rainfall and relative humidity during 15 July and 15 August 2011.

Table 5 shows the effect of transplanting time as affected by ShB on yield and yield components of BRRI dhan49. Higher number of panicle $\mathrm{m}^{-2}$ (266) was counted in 30 August transplanting. The number of panicles was comparatively low (244) in 15 August transplanting. There was no difference in number of panicles $\mathrm{m}^{-2}$ between 30 July (263) and 30 August transplanting. Similarly, 15 July (257) and 15 August transplanting did not vary in panicle numbers $\mathrm{m}^{-2}$. There was a statistical variation in number of filled grains panicle-1 among the transplanting dates. Number of filled grains panicle ${ }^{-1}$ was 141 in 30 July transplanting as compared to 134 in 15 July transplanting. The difference was insignificant. The lowest number of filled grains panicle ${ }^{-1}$ (127) was counted in 30 August transplanting. Variation in number of unfilled grains was also significant. Statistically, among the dates of transplanting, the maximum number of unfilled grains (74) was counted in 30 August transplanting, which was significantly different from that in 15 August transplanting (62). Transplanting in 15 July and 30 July did not differ in number of unfilled grains. Number of unfilled grains was the lowest (39) in 30 July transplanting.

There were also significant differences among the transplanting dates for grain yield. Yield was significantly higher (5.82 $\left.\mathrm{t} \mathrm{ha}^{-1}\right)$ in 30 July transplanting as compared to $5.17 \mathrm{t} \mathrm{ha}^{-1}$ in case of 15 July transplanting, but the difference was not significant (Table 5). The plots transplanted on 15 August produced $4.56 \mathrm{t} \mathrm{ha}^{-1}$ grain yields and that of 30 August produced $4.27 \mathrm{t} \mathrm{ha}^{-1}$. The difference was insignificant but the difference in grain yield between 30 July and 30 August transplanting was significant. Yield loss estimated to the range of $40.0-1780.0$ $\mathrm{kg} \mathrm{ha}^{-1}$ (Ali, 2002) and 135.9 to $762.2 \mathrm{~kg} \mathrm{ha}^{-1}$ (Anonymous, 2003). For different transplanting dates, a sheath infection did not affect the grain size of BRRI dhan49. The 1000 grain weight was $20 \mathrm{~g}$ in each transplanting date during T. Aman 2011.

Table 4. Effect of ShB disease as influenced by planting time on yield and yield components of BRRI dhan49 during T. Aman 2010.

\begin{tabular}{cccccc}
\hline Treatment & Panicle $\mathrm{m}^{-2}$ & $\begin{array}{c}\text { Filled grain } \\
\text { panicle }{ }^{-1}\end{array}$ & $\begin{array}{c}\text { Unfilled grain } \\
\text { panicle }^{-1}\end{array}$ & $\begin{array}{c}1000 \text { grain weight } \\
(\mathrm{g})\end{array}$ & Yield (t ha-1) \\
\hline $\mathrm{T}_{1}$ & $257 \mathrm{a}$ & $145 \mathrm{a}$ & $45 \mathrm{c}$ & 20 & $5.67 \mathrm{~b}$ \\
$\mathrm{~T}_{2}$ & $263 \mathrm{a}$ & $151 \mathrm{a}$ & $39 \mathrm{c}$ & 20 & $6.29 \mathrm{a}$ \\
$\mathrm{T}_{3}$ & $244 \mathrm{~b}$ & $127 \mathrm{~b}$ & $63 \mathrm{~b}$ & 20 & $4.17 \mathrm{c}$ \\
$\mathrm{T}_{4}$ & $268 \mathrm{a}$ & $116 \mathrm{c}$ & $74 \mathrm{a}$ & 20 & $3.80 \mathrm{c}$ \\
LSD $(\mathrm{P}=0.05)$ & 15.49 & 8.84 & 8.84 & $\mathrm{NS}$ & 0.55 \\
\hline
\end{tabular}

$\mathrm{T}_{1}=15$ July, $\mathrm{T}_{2}=30$ July, $\mathrm{T}_{3}=15$ August and $\mathrm{T}_{4}=30$ August transplanting. Means followed by the same letter in a column did not differ significantly at the $5 \%$ level by LSD. NS= Not Significant. 
Table 5. Effect of ShB as influenced by planting time on yield and yield components of BRRI dhan49 during T. Aman 2011.

\begin{tabular}{cccccc}
\hline Treatment & Panicle $\mathrm{m}^{-2}$ & Filled grain panicle $\mathrm{e}^{-1}$ & $\begin{array}{c}\text { Unfilled grain } \\
\text { panicle }\end{array}$ & $\begin{array}{c}\text { 1000 grain } \\
\text { weight }(\mathrm{g})\end{array}$ & ${\text { Yield }\left(\mathrm{t} \mathrm{ha}^{-1}\right)}^{-1}$ \\
\hline $\mathrm{T}_{1}$ & $257 \mathrm{ab}$ & $134 \mathrm{ab}$ & $45 \mathrm{c}$ & 20 & $5.17 \mathrm{a}$ \\
$\mathrm{T}_{2}$ & $263 \mathrm{a}$ & $141 \mathrm{a}$ & $39 \mathrm{c}$ & 20 & $5.82 \mathrm{a}$ \\
$\mathrm{T}_{3}$ & $244 \mathrm{~b}$ & $136 \mathrm{a}$ & $62 \mathrm{~b}$ & 20 & $4.56 \mathrm{~b}$ \\
$\mathrm{~T}_{4}$ & $266 \mathrm{a}$ & $127 \mathrm{~b}$ & $74 \mathrm{a}$ & 20 & $4.27 \mathrm{~b}$ \\
$\mathrm{LSD}(\mathrm{P}=0.05)$ & 15 & 8.40 & 8.84 & $\mathrm{NS}$ & 0.80
\end{tabular}

$\mathrm{T}_{1}=15$ July, $\mathrm{T}_{2}=30$ July, $\mathrm{T}_{3}=15$ August and $\mathrm{T}_{4}=30$ August transplanting. Means followed by the same letter in a column did not differ significantly at the $5 \%$ level by LSD. NS=Not Significant.

\section{CONCLUSIONS}

In Bangladesh, ShB is a very notorious fungal disease for almost every season. Method for controlling the disease is an urgent need. The minimum RLH was observed in 30 July followed by 15 July transplanting and the maximum PDI in 30 August followed by 15 August transplanting for both the years. Moreover, the highest yield was recorded in 30 July and the lowest in 30 August transplanting during both the seasons. Finally, integrated disease management (IDM) packages need to be developed by using appropriate planting time, cultural practices and fungicides to control ShB disease of rice.

\section{ACKNOWLEDGEMENT}

This study was the part of the corresponding author's $\mathrm{PhD}$ dissertation. The author acknowledges the scholarship and financial support given by NATP, BARC, Dhaka and research facilities provided by Plant Pathology Division, BRRI, Gazipur.

\section{REFERENCES}

Ali, M A, M M Rahman, M A Latif, M Hossain, N R Sharma, S Akter, T A Mia and M A Nahar. 2003. Survey of rice sheath blight disease caused by different Rhizoctonia sp. in Bangladesh. In. Paper presented in the stakeholder workshop on rice sheath blight disease complex, Bangladesh Rice Research Institute (BRRI), Gazipur, Bangladesh, 3 December 2003.

Ali, M A. 2002. Biological variation and chemical control of Rhizoctnia solani causing rice sheath blight in Bangladesh, PhD thesis, Department of Biological Sciences, Imperial College for Science, Technology and Medicine, Silwod Park, Ascot, Berkshire, United Kingdom.

Anonymous. 2003. Survey report on rice sheath blight disease complex. In. Paper presented in the workshop under DFID-BRRI collaborative project, 3$4^{\text {th }}$ December 2003, Plant Pathology Division, BRRI, Gazipur 1701, Bangladesh.

Anonymous. 2006. World Rice Statistics. International Rice Research Institute, Los Banos, Laguna, Metro Manila, Philippines.

Anonymous. 2010. Modern Rice Cultivation (Adhunik Dhaner Chas-Bangla version). Publication no. $5,15^{\text {th }}$ Edition. Bangladesh Rice Research Institute, Gazipur 1701, Bangladesh.

Anonymous. 2018. Modern Rice Cultivation (Adhunik Dhaner Chas-Bangla version). Publication no. 5, $21^{\text {th }}$ Edition. Bangladesh Rice Research Institute, Gazipur 1701, Bangladesh.

Ashrafuzzaman, M H, M Jalaluddin, M I Kha1il and I Hossain. 2005. Integrated management of sheath blight of Aman rice. Bangladesh J. Plant. Pathol. 21 (1 and 2): 53-58.

Bhaktavatsalam, G, K Satyanarayana, A P K Reddy and V T John. 1978. Evaluation for sheath blight resistance in rice. Int. Rice Res. Newsl. 3: 9-10.

Brooks, S A. 2007. Sensitivity to a Phytotoxin from Rhizoctonia solani correlates with sheath blight susceptibility in Rice. Phytopathology 97: 1207-1212.

Damicone, J R, M V Patel and W F Moore. 1993. Density of sclerotia of Rhizoctonia solani and incidence of sheath blight in rice fields in Mississippi. Pl. Dis. 77(3): 257-260.

Dilla, E M. 1993. Yield loss due to sheath blight in directseeded rice as affected by plant density, nitrogen level and amount of inoculum. College, Los Banos, Laguna, Metro Manila, Philippines. p. 175. 
Gangopadyay, S and N K Chakrabarti. 1982. Sheath blight on rice. Review of Plant Pathololgy 61: 451-460.

Groth, D E, M C Rush and C A Hollier. 1991. Rice diseases and disorders in Louisiana. La. Agric. Exp. Stn. Bull. No. 828.

Groth, D E, M C Rush and C A Hollier. 1992. Prediction of rice sheath blight severity and yield loss based on early season infection. La. Agric. 35: 20-23.

Hashiba, T, T Yammaguchi and S Mogi. 1977. Quantitative changes in nitrogen and starch content in rice sheaths during vital disease development of sheath blight caused by Rhizoctonia solani Kuhn. Ann. Phytopath. Soc. Japan 43: 1-8.

IRRI. 2002. Standard evaluation system for rice. Rice Knowledge Bank, International Rice Research Institute, Los Banos, Laguna, Metro Manila, Philippines. p.19.

Kozaka, T. 1975. Sheath blight in rice plants and its control. Rev. Plant Prot. Res. 8: 69-79.

Lakpale, N, K C Agrawal, V S Thrimurty and A S Kotasthana. 1994. Influence of submergence on sclerotial viability of Rhizoctonia solani causing sheath blight of rice. Adv. Pl. Sci. 7(1): 143-146.

Leano, R M. 1993. Ecological factor associated with sheath blight epidemiology and yield loss in rice (Oryza sativa L.). College, Los Banos, Laguna, Metro Manila, Philippines. pp. 82.

Marchetti, M A and CN Bollich. 1991. Quantification of the relationship between sheath blight severity and yield loss in rice. Plant Dis. 75: 773-775.
McKinney, H H. 1923. A new system of grading plant diseases. Journal of Agriculture Research 26: 195218.

Miah, S A and A K M Shahjahan. 1987. Mathe Dhaner Rog Nirnoy O Tar Protikar (Bangla Version). Bangladesh Rice Research Institute, Gazipur, Bangladesh. pp. 60.

Nagarajkumar, M, R Bhaskaran and R Velazhahan. 2004. Involvement of secondary metabolites and extracellular lytic enzymes produced by Pseudomonas fluorescens in inhibition of Rhizoctonia solani, the rice sheath blight pathogen. Microbiological Research 159: 73-81.

Naidu, V D. 1992. Influence of sheath blight of rice on grain straw yield in some popular local varieties. J. Res. Publ. 10: 78-80.

Shahjahan, A K M, N R Sharma, H U Ahmed and S A Miah. 1986. Yield loss in modern rice varieties of Bangladesh due to sheath blight. Bangladesh J. of Agricultural Research 11(2): 82-90.

Sharma, N R and P S Teng. 1990. Effects of inoculum source on sheath blight development. Int. Rice Res. Newsl. 15: 18-19.

Ui, T, T Naiki and M Akimoto. 1976. A saving-floatation technique using hydrogen peroxide solution for determination of sclerotial population of Rhizoctonia solani Kuhn in soil. Ann. Phytopath. Soc. Japan 42: 46-48.

Wu, W, J Huang, K Cui, L Nie, Q Wang, F Yang, F Shah, F Yao and S Peng. 2012. Sheath blight reduces stem breaking resistance and increases lodging susceptibility of rice plants. Field Crops Research 128: 101-108. 